\title{
Qualitative analysis of the health promotion work in a Academia da Saúde programme's unit
}

\section{Análise qualitativa do trabalho em promoção da saúde em uma unidade do programa Academia da Saúde}

\section{AUTHOR'S \\ Heidi Jancer Ferreira ${ }^{1,2}$ (D) \\ David Kirk ${ }^{3,4}$ (DD \\ Alexandre Janotta Drigo ${ }^{1}$ (C) \\ 1 São Paulo State University, Post-graduate \\ Program of Human Movement Sciences, Rio Claro, \\ São Paulo, Brazil. \\ 2 Federal Institute of Education, Science and \\ Technology of South of Minas Gerais, Poços de \\ Caldas, Minas Gerais, Brazil. \\ 3 University of Strathclyde, School of Education, \\ Glasgow, United Kingdom. \\ 4 University of Queensland, School of Human \\ Movement and Nutrition Sciences, Brisbane, \\ Australia.}

\section{CORRESPONDING}

Heidi Jancer Ferreira

heidi.ferreira@ifsuldeminas.edu.br

Avenida Dirce Pereira Rosa, n. 300, Poços de

Caldas, Minas Gerais, Brasil.

CEP: 37713-100.

DOI

$10.12820 /$ rbafs. $25 \mathrm{e} 0128$

\begin{abstract}
The Academia da Saúde programme has been considered an important health promotion strategy in the scope of primary health care in Brazil. However, there is little evidence on what and how professional practices have been developed as a means to enact health promotion processes in the programme. The study's purpose was to analyse the health promotion work in a Academia da Saude programme's unit from Lajeado city, Brazil. The study employed a qualitative approach and grounded theory research method. Participants included a female Health and Physical Education professional (aged 32y), a female health centre coordinator (aged 41y) and eight users (2 men, 6 women, aged 30-69y). Data were collected through condensed fieldwork, involving interviews and non-participant observation of group sessions. Using salutonegesis theory, qualitative analysis generated key findings on the elements of the health promotion work, namely: holistic care, use of diversification into cognitive, psychosocial and physical activities, development of skills and capacities that served as health resources, and the occurrence of resistance and challenges in the programme. Furthermore, the findings offered practical examples of possibilities to enact health promotion process, which represents a significant contribution to knowledge on health work. The study may support both future interventions and professional education, indicating alternative pathways for practitioners and undergraduate students to widen the scope of health promotion actions beyond the biophysical dimension.
\end{abstract}

Keywords: National health programs; Community health services; Professional practice; Holistic health; Health resources.

\section{RESUMO}

O programa Academia da Saúde tem sido considerado uma importante estratégia de promoção da saúde no âmbito da atenção primária à saúde no Brasil. Entretanto, existem poucas evidências sobre quais e como práticas profissionais têm sido desenvolvidas como forma de operacionalizar processos de promoção da saúde no programa. O objetivo do estudo foi analisar o trabalho de promoção da saúde em uma unidade do programa Academia da Saúde de Lajeado, Brasil. O estudo empregou uma abordagem qualitativa e o método de pesquisa da teoria fundamentada nos dados. Os participantes incluíram uma profissional de Educação Física (32 anos), uma coordenadora de centro de saúde (41 anos) e oito usuários (2 homens, 6 mulheres, 30-69 anos). Os dados foram coletados por meio do trabalho de campo condensado, envolvendo entrevistas e observaçẫo não-participante das atividades coletivas. Utilizando a teoria da salutogênese, a análise qualitativa gerou os resultados sobre os elementos do trabalho de promoção da saúde, a saber: cuidado holístico, uso da diversificação em atividades cognitivas, psicossociais e físicas, desenvolvimento de habilidades e capacidades que serviram como recursos de saúde, e a ocorrência de resistências e desafios no programa. Além disso, os resultados ofereceram exemplos práticos de possibilidades para mobilizar o processo de promoção da saúde, 0 que representa uma contribuição significativa para o conhecimento sobre o trabalho em saúde. O estudo pode subsidiar intervençôes futuras e a formação profissional, indicando caminhos alternativos para profissionais e estudantes de graduação ampliarem o escopo das ações de promoção da saúde para além da dimensão biofísica.

Palavras-chave: Programas nacionais de saúde; Serviços de saúde comunitários; Prática profissional; Saúde holística; Recursos de saúde.
This work is licensed under a Creative Commons Attribution 4.0 International License. ticulation between federal and municipal government levels and expansion of health promotion actions in a community scale ${ }^{1-3}$.

The ASP is government-sponsored and supported by political health policies that convey a set of principles and guidelines aligned with the health promotion frame- 
work, such as comprehensive care, popular participation, and cross-sectorial work ${ }^{4-5}$. It is already known that Health and Physical Education professionals (HPEP) prevail as workforce in the ASP and the activities that are often conducted involve group interventions directed at regular physical activity and healthy eating habits ${ }^{3,6-7}$. Studies $^{8-11}$ have also demonstrated that the majority of ASP's users are middle-age and older women, who showed high levels of satisfaction with the programme and perceptions of increased quality of life, pleasure and social interaction as resulting from their participation.

In order to advance ASP's actions, it is crucial to understand what practices are associated with positive health outcomes perceived by users. In this respect, previous research ${ }^{2,12-3}$ revealed HPEP's perceptions of the objectives, object, products and difficulties of their work, and representations of the concepts of health and illness that informed their practices. However, there is still a need of conducting further research on what practices and how they have been developed as a means to enact health promotion processes in the ASP. Additionally, several studies on the ASP have focused on pioneering units on implementing the programme,

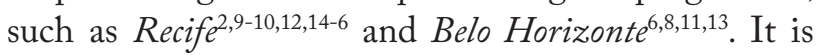
also relevant to gain understanding about the implementation and functioning of recent units, and how practices of health promotion in the ASP have evolved in other contexts. In this sense, this study aimed to analyse the health promotion work in a unit of the ASP from Lajeado city, Brazil.

\section{Methods}

The study employed a qualitative approach and grounded theory research method ${ }^{17}$. By using grounded theory, the researcher creates a theoretical explanation that is grounded in data and clarifies the relationship among identified conditions, causes and consequences of a particular situation ${ }^{17}$.

The study's setting was a unit of the ASP, located in Lajeado city, southern Brazil. Theoretical sampling guided the selection of the site. This strategy has a logic of sampling that is intentional and theoretically driven, which means the researcher seeks pertinent and relevant data to develop a theoretical explanation about the research problem ${ }^{17}$. The main criterion for selecting the site was relevance to the study. Relevance was defined according to available information about the ASP unit that suggested the adoption of a wide view of health, focusing on mental, social and/or emotional aspects, beyond the physical dimension.

Participants included one HPEP, one health centre coordinator and eight users who were enrolled in the ASP. The HPEP (female, 32 years old) held a bachelor's degree in Physical Education and had three years of professional experience in the ASP. The health centre coordinator (female, 41 years old) had a bachelor's degree in Nursing and two years of professional experience in the job position. A characterisation of the eight ASP unit's users is provided in table 1.

Table 1 - Characterisation of the ASP unit's users $(n=8)$.

\begin{tabular}{lccccc}
\hline Users & $\begin{array}{c}\text { Occupational } \\
\text { situation }\end{array}$ & Gender & $\begin{array}{c}\text { Marital } \\
\text { status }\end{array}$ & Educational level & $\begin{array}{c}\text { Age } \\
\text { (years) }\end{array}$ \\
\hline U1 & Retired & Female & Married & Lower Secondary & 46 \\
U2 & Retired & Female & Widow & Primary & 55 \\
U3 & Retired & Male & Single & Incomplete Upper & 69 \\
& & & Secondary & \\
U4 & Retired & Female & Married & Upper Secondary & 62 \\
U5 & Retired & Male & Married & Lower Secondary & 69 \\
U6 & Housewife & Female & Widow & Incomplete Lower & 66 \\
& & & Secondary & \\
U7 & Machine & Female & Married & Lower Secondary & 46 \\
& Operator & & & Bachelor degree & 30 \\
U8 & Architect & Female & Single & Ban
\end{tabular}

Data were generated by condensed fieldwork ${ }^{18}$ in October, 2018. In doing condensed fieldwork, the first author spent a limited number of days in the field, that is, a visit in loco during three following days. Data sources included semi-structured interviews with participants and non-participant observation of group sessions. Fourteen hours of non-participant observation were conducted of group sessions of eleven classes in the ASP unit. A non-systematic observation technique called anecdotal record ${ }^{19}$ was employed to provide information on what was happening related to categories that were previously established by the researchers, like instructional aspects (climate, structure of sessions, time allocation, types of activities, HPEP's behaviour and strategies), users' behaviour and response to activities, environment and context, interactions and conversations.

At the beginning of each session, the HPEP introduced the researcher, who explained the research project. At this time, a user per class, who was over 18 years old and with longer time of participation, was invited to participate in an interview. There was no refusal of users to participate in the research.

The interviews, lasting approximately 35 minutes each (five hours in total), were conducted in pairs with 
eight users, and individually with the HPEP (four interview sessions) and health centre coordinator (a single session). They were audio recorded with participants' agreement and transcribed verbatim. Structured questions were asked in order to identify participants' sociodemographic information. Next, open-ended questions were asked to explore the main research topics, according to stakeholders' group. The HPEP was asked about professional experiences, the programme unit's history, community's profile, goals and aspirations that guided the work process, contents, methods, monitoring strategies, resources, and results. The health centre coordinator was asked about the community's profile and perceptions about the ASP's impact on community's health development. With the users, the interview covered topics about their experiences, meanings and perceptions related to their participation in the ASP.

Data were analysed through the constant comparative method ${ }^{17}$, using open, axial and selective coding ${ }^{20}$. The analytical process involved several steps. After systematic reading, initial codes were constructed by a process of studying data in detail and naming segments to represent what was observed from the empirical content (open coding). The second step of axial coding allowed the researchers to explore the data, make more comparisons across the codes and establish relationships between them, relating subthemes to themes. Then, through selective coding, further constant comparisons were made to develop themes and select the most relevant, a process that generated a core theme and three subthemes as an explanation of the health promotion work in the ASP. Finally, in order to theoretically develop the findings, they were brought into relation to the literature on health promotion, with emphasis on salutogenesis theory ${ }^{21-3}$.

As a theory for health promotion, salutogenesis proposed to focus on what makes people stay healthy (salutary factors) instead of asking what are the causes of certain diseases (risk factors). For the purpose of data analysis, the study concentrated on the salutogenic concept of health resource ${ }^{24}$ originally called as generalised resistance resource ${ }^{21}$, which can be defined as any characteristic or factor that a person or community could draw upon to cope with challenging situations in everyday life and, in so doing, stay healthy. A health resource could be built from one's inner and external world (e.g. personality, culture, environment), and it could help people to see their lives as comprehensible, manageable and meaningful.
The research was carried out according to ethical procedures, after approval by the Ethics Committee on Human Research - São Paulo State University registered by reports n.1.548.237, n.2.606.554, n. 2.739 .561 and n. 3.573.017. Additionally, the study was authorised by Núcleo Municipal de Educação em Saúde Coletiva of Lajeado.

\section{Findings}

Findings are presented in terms of a description of the ASP unit from Lajeado and the themes that were generated throughout qualitative analysis as elements of the health promotion work.

The unit was implemented in 2016, adjacent to a primary health care centre in Lajeado city. A description of the ASP (Figure 1) was elaborated following the basic structure of theoretical-logical model, which is a useful tool for planning, implementing and evaluating programmes ${ }^{25}$.

Overall, the unit's purpose was to provide services related to bodily practices and physical activity, health education, promotion of healthy diet and production of care in public spaces, under professional supervision.

Qualitative analysis generated a main theme - holistic care, which was interrelated with three subthemes - diversification into activities, development of health resources, and resistance and challenges. Holistic care was related to the integration of physical, mental and social dimensions of health in the delivery of activities. It involved professional attitudes, beliefs and strategies that sought to address the psychological needs of users in addition to the biophysical ones. In the context of the study, health promotion actions included the provision of activities directed at the development of emotional and social skills, beyond exercise prescription.

In line with a comprehensive view of health, the HPEP described the goals that guided the work in the ASP:

There are three things that I understand from the programme: first, it is concerned with health promotion and disease prevention; second is its focus on participants' physical, mental and social aspects. This is the most important thing for me. And third, it aims to show attentiveness to community, which I also think is fundamental. This is a matter of people feeling good and not wanting to leave. (HPEP)

Users' comments suggested that the means used by the HPEP to achieve the ASP's goals drew on stimu- 


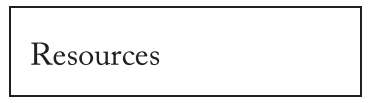

Human resource:
$1 \mathrm{HPEP}$

Financial resource:
government-
sponsored

\begin{tabular}{|l|}
\hline \\
Material resource: \\
fitness materials, \\
including stick, \\
whiteboard, chair, \\
dumbbell, mini \\
trampoline, step, \\
elastic fitness \\
band, mat, rope, \\
hoop, balls and \\
exercise cone \\
\end{tabular}

\begin{tabular}{|l|}
\hline Activities \\
\hline $\begin{array}{l}\text { Group sessions of } \\
\text { bodily practices } \\
\text { and physical } \\
\text { activity (chair- } \\
\text { based, low impact } \\
\text { and free weight } \\
\text { exercise, games, } \\
\text { recreation, group } \\
\text { dynamics) }\end{array}$ \\
\hline
\end{tabular}
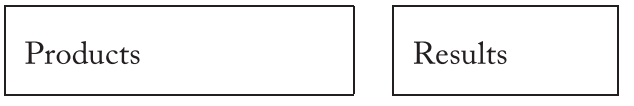

Goal and

target

\begin{tabular}{|l|}
\hline $\begin{array}{l}\text { Educational short } \\
\text { talks on health- } \\
\text { related topics }\end{array}$ \\
\hline $\begin{array}{l}\text { Workshops about } \\
\text { healthy eating } \\
\text { habits and nutrition }\end{array}$ \\
\hline
\end{tabular}

\begin{tabular}{|l|}
\hline $\begin{array}{l}\text { Recreational and } \\
\text { social events }\end{array}$ \\
\hline $\begin{array}{l}\text { Community } \\
\text { actions }\end{array}$ \\
\hline
\end{tabular}
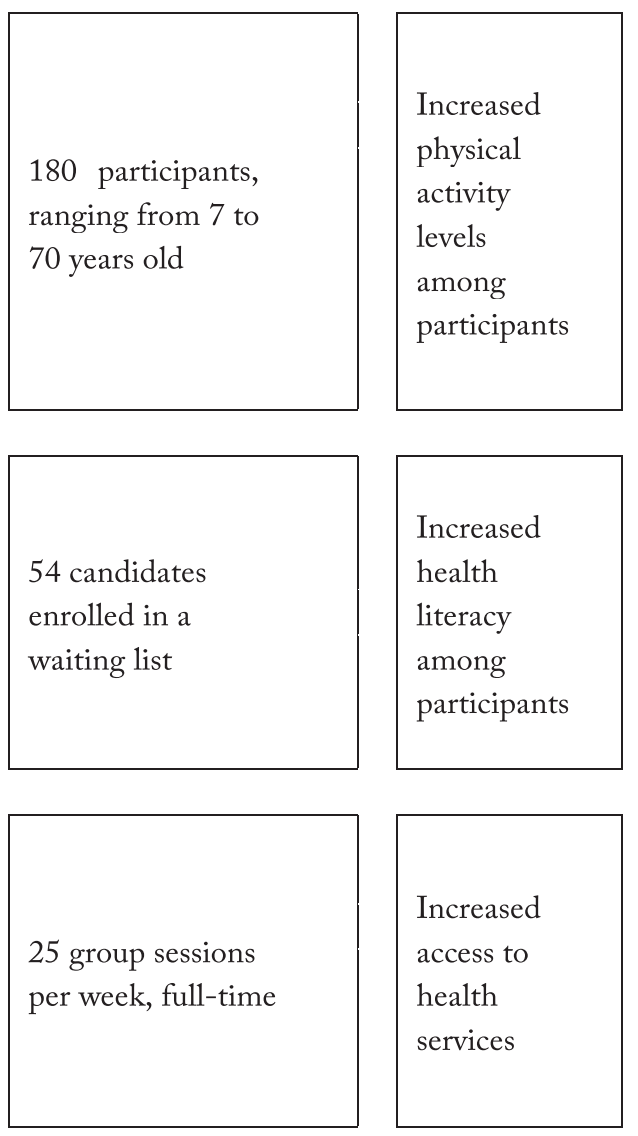

\begin{tabular}{|l|}
\hline Contribute \\
to health \\
promotion, \\
disease \\
prevention \\
and \\
development \\
of physical, \\
mental and \\
social \\
dimensions \\
of \\
individuals \\
and \\
community \\
\end{tabular}

Influencing factors: easy community access to the location; availability of indoor and outdoor physical activity space; autonomy of HPEP to develop work processes; instability of the HPEP's working contract; non-existence of Family Health Support team; lack of other health professionals.

Figure 1 - Theoretical-logical model of the ASP unit from Lajeado. Source: Elaborated by the authors, following Romeiro et al..$^{25}$.

lating different domains of health through group sessions of physical activity and bodily practices.

It is not just the exercise that she works with us. She works on mentality, concentration... and the friends that we make here. That's really good. (U7) I'd never had contact with this kind of work. So, for me the social aspect is the most motivating (...)

Here, you already know that the purpose is different (...) I think when you understand that the purpose isn't only come here to exercise, things get much easier (...) So, it's always very well explained that there are these social and mental issues, and physical activity. (U8)
The subtheme 'diversification into activities' indicated that a wide range of activities were employed as a major strategy to address the physical, mental and social needs of participants, which enabled the development of holistic care in the programme. Fieldnotes indicated that types of activities included psychosocial group dynamics, cognitive tasks, recreation, games, aerobics with music, muscle strengthening and stretching. As the HPEP commented:

I always want to bring new things to escape from physical activity. (...) Every day is a different class. (...) At least once a week, I try to do an activity that takes a little longer. (HPEP) 
The longer activities mentioned by the HPEP included mainly psychosocial group dynamics, recreation and games directed at the development of psychosocial abilities. Diversified activities were organised to respond to participants' health needs, which were increasingly related to psychological issues, as reported by the health centre coordinator. During observed sessions, such activities appeared to be challenging and enjoyable for participants, as they took some time to complete tasks and reacted with laughs and clues to their colleagues. Examples of activities are shown in Box 1.

A user confirmed that the HPEP stimulated them through a variety of activities.

Every day is different, she changes. Another thing is that she asks a lot of questions. She makes us read messages. Each one had to bring and read a message for the others. She does games for us to write, to discover things, to open the mind. This is very cool. (U2)

Another activity that the HPEP carried out to increase socialisation was organisation of events, mainly during special dates. Fieldnotes reported examples of events that were identified through a set of photos on the session room and HPEP's files, such as children's day, decoration of a community Christmas tree, chocolate treasure hunt in Easter, the ASP unit's anniversary and festivals like festa junina and farroupilha week. Other activities were expanded to community life as a means of nurturing social support, solidarity and cooperation among participants. For instance, the users got together for having lunch, celebrating birthdays, gardening in community spaces, and acting as blood donors.

Also, as part of the activities of the ASP, health education practices occurred through an integration of health professionals (e.g. nurse, physiotherapist, dietitian), who provided short lectures and workshops about health-related topics. Therefore, diversification into activities enabled the users to be stimulated in different ways and develop a range of life skills, which is connected with the next subtheme, the development of health resources.

Importantly, the users perceived that their skills set (communicative, emotional, cognitive and social skills) changed from a deficit status into a positive perspective, as resources they might draw upon to improve their health and wellbeing. Then, the second subtheme refers to health resources perceived by the users relating to their participation in the ASP, which they may activate to support them in the process of health promotion. The health resources that were identified are shown in Table 2.

The development of health resources suggests that the ASP's health promotion work had a positive impact on the users' capacity of comprehending their lives and dealing with challenging situations, thus, experiencing health development.

Nevertheless, the HPEP reported that participants responded to activities in different ways, which means that negative attitudes were noted throughout the work process, such as opposition to have new experiences that were not focused on traditional physical

Box 1 - Examples of activities delivered in group sessions to develop psychosocial abilities.

\begin{tabular}{|c|c|}
\hline Psychosocial abilities & Example of activities \\
\hline Self-esteem & $\begin{array}{l}\text { There was a box and a person would take the box and open it to see the gift inside. The person opened and there was a } \\
\text { mirror. Then, she would look at herself. She could not tell her colleagues what was in the box, but she had to describe } \\
\text { what she was seeing (...) (HPEP) }\end{array}$ \\
\hline $\begin{array}{l}\text { Reflection and meaning making, } \\
\text { interaction, conversation }\end{array}$ & $\begin{array}{l}\text { Guys, I'm going to speak body parts and I'll put my hand in one of them. You have to put your hand where I say, not } \\
\text { in the same body part that I put it (...) I started, 'Guys, you know that story about do what I say, but don't do what } \\
\text { I do? Do you do it in your lives? For example, you say don't smoke because it isn't good, but then you smoke at the } \\
\text { weekend'? (HPEP) }\end{array}$ \\
\hline \multirow[t]{2}{*}{ Communication and confidence } & $\begin{array}{l}\text { They had to bring a message to read at loud (...) When someone finished the reading, we made comments on what } \\
\text { was read. (HPEP) }\end{array}$ \\
\hline & $\begin{array}{l}\text { Each one picked a name of a secret friend and made a draw of the person on the board. The others tried to guess who } \\
\text { was the secret person. (Researcher's fieldnotes) }\end{array}$ \\
\hline Self-expression & $\begin{array}{l}\text { I love doing activities on the whiteboard. For example, to write what they like and dislike in winter. At the beginning } \\
\text { of the year we did what we wanted for the new year. On the woman's day, we did about what means to be a woman. I } \\
\text { write and each one has to say a word. (HPEP) }\end{array}$ \\
\hline $\begin{array}{l}\text { Awareness, perception, empathy, } \\
\text { interaction }\end{array}$ & $\begin{array}{l}\text { I slipped a piece of paper on each one's back. And they had to write on someone's back. Everyone had to write on } \\
\text { everybody's back and say what they thought of the person. (HPEP) }\end{array}$ \\
\hline Memory and concentration & $\begin{array}{l}\text { The HPEP chose an alphabet letter for the round. One by one, she assigned a different theme (e.g. name, city, } \\
\text { dream, food, and others) to each participant, who should say a word that began with the chosen letter. (Researcher's } \\
\text { fieldnotes) }\end{array}$ \\
\hline
\end{tabular}


Table 2 - Health resources perceived by users $(n=8)$ relating to their participation in the ASP.

\begin{tabular}{|c|c|c|c|}
\hline Health resources & Users & Total & Examples of units of analysis \\
\hline $\begin{array}{l}\text { Friendship and social } \\
\text { interaction }\end{array}$ & $1-8$ & 8 & $\begin{array}{l}\text { Coming here, I made friends. (U6) } \\
\text { Social interaction has improved a lot, having access to people of various age groups is also something } \\
\text { that I found very cool. (...) So, I really liked it, but mainly the social side. (U8) }\end{array}$ \\
\hline Health-related knowledge & $1-8$ & 8 & $\begin{array}{l}\text { The teacher brings lectures by dietitian, physiotherapist ... So, we learn a lot. That's really good. (...) } \\
\text { Then it makes a complete set. (U2) }\end{array}$ \\
\hline Social support & $1-4,7,8$ & 6 & $\begin{array}{l}\text { We donate blood, we visit those who have problems }(\ldots) \text { When someone is missing in the group } \\
\text { because of illness, we get together and go to the person's house. So, one helps the other, one shares } \\
\text { with the other what one has. We bring clothes to donate, whatever we have at home and don't use } \\
\text { anymore, we bring here. (U4) }\end{array}$ \\
\hline $\begin{array}{l}\text { Communication and } \\
\text { sociability }\end{array}$ & $1-3,5,6,8$ & 6 & Even to be with people, I don't know, it changes totally. We become more sociable and joyful. (U1) \\
\hline $\begin{array}{l}\text { Physical fitness and positive } \\
\text { body perception }\end{array}$ & $1-6$ & 6 & I was rusty. Now I can move my legs back and forth (...) It's a great thing. For us it is excellent. (U5) \\
\hline Habit of exercising & $1-5$ & 5 & $\begin{array}{l}\text { We exercise three times a week. We move a lot. So, everything helps. At this age that we are, it's } \\
\text { important to be able to move a little bit, do activity. While I can, I will do. (U5) }\end{array}$ \\
\hline $\begin{array}{l}\text { Disease control and pain } \\
\text { relief }\end{array}$ & $1,3,4,6,7$ & 5 & $\begin{array}{l}\text { I had high blood pressure and today I don't have it. I have diabetes but controlled. Before I had no } \\
\text { control. (...) I used to take two pills a day and today I take none. It happened through this programme } \\
\text { here. (U3) }\end{array}$ \\
\hline Positive energy and mood & $1-4,6$ & 5 & $\begin{array}{l}\text { More energy. More energy. Because I sometimes did not have willingness to do something at home. } \\
\text { Now it's totally different. I have more willingness to do things. (U1) }\end{array}$ \\
\hline Cognition and memory & $4,6,7$ & 3 & $\begin{array}{l}\text { We also learn a lot from the teacher in this sense because she (...) works with balance and we end up } \\
\text { working the mind, brain, memory ... Even the memory has improved. (U4) }\end{array}$ \\
\hline Self-esteem & 1,4 & 2 & I think it improves self-esteem (...) It changed a lot, a lot. (U4) \\
\hline
\end{tabular}

activity. Hence, the ASP's health promotion work was also characterised by resistance and challenges. As the HPEP commented:

So, we touch people sometimes, in some way. Because there are people who are really trying to take advantage of something. But there are people who aren't taking advantage of anything. (HPEP)

Not only resistance, but also challenges were identified, for instance, a limited capacity to attend all people who demonstrated an interest to register in, culminating with a waiting list (54 persons at the time of the study). Moreover, the HPEP indicated time constraints to give personalised attention to users and to implement a structured assessment due to her high workload. In face of these challenges, the HPEP suggested that more professionals were needed in order to attend existing demands and to expand the array of activities. Another problem was related to a lack of professional knowledge on articulation of actions across sectors and health services, in order to collaboratively address community health issues.

In short, the findings confirmed that, despite the difficulties, the ASP's work process was aligned with health promotion theoretical framework. Further, it can be associated with users' positive experiences and self-perception of improved health and wellbeing.

\section{Discussion}

Qualitative analysis of the health promotion work of the ASP unit from Lajeado showed that it was characterised by holistic care, demonstrating to be consistent with health promotion literature, including salutogenesis theory ${ }^{21-3}$. Holistic care was enabled by the strategy of diversification into activities. Nonetheless, the health promotion work did not occur effortlessly and demonstrated to be complex, as resistance and challenges emerged throughout the process. Notwithstanding, it led to the development of health resources among users, allowing them to see their lives as more comprehensible, manageable and meaningful.

The findings indicated that the ASP unit drew on group sessions of physical activity and bodily practices, health education actions, promotion of healthy eating habits and community mobilisation, similarly to other units investigated in Brazil ${ }^{3,6-7,14}$. Major goals of the HPEP's professional practices in the ASP involved health promotion, disease prevention, and the development of social, mental and physical dimensions of health. This finding connects to Guarda et al. ${ }^{12}$ study of the objectives of HPEP' work in ASP (i.e. health promotion, quality of life, promotion of healthy behaviours, physical activity, leisure, social interaction 
and self-care). This close correspondence was expected given that the ASP is a national programme, framed by official documents ${ }^{4-5}$ that offered guidance on subjects and activities to be developed. A distinctive point about the ASP unit from Lajeado was related to the attendance of children and adolescents, provided that only $36 \%$ of ASP units in Brazil were able to attend both older and younger age groups ${ }^{3}$.

In addition to the findings from previous research on work processes in the $\mathrm{ASP}^{2,12}$, the results of this study highlighted that the main means used to nurture health promotion was holistic care through the delivery of group activities. Holistic care has its philosophical basis on holism, which acknowledges the person as a whole human being and the interdependence among physical, physiological, psychological, social and spiritual aspects of one's life ${ }^{26}$. By assuming a holistic perspective, all dimensions of users were considered of importance to health promotion work, adding meaningfulness to their lives.

As a strategy to enact holistic care, the use of diversification into activities aligns with previous studies ${ }^{27-8}$ that highlighted the importance of inserting variation in the delivery of services for older age groups to make activities more attractive and enjoyable for them. Consistently, the ASP's users recognised that experiencing diversified activities was meaningful to them.

As a result, the use of a range of recreational activities, events, psychosocial group dynamics and health education practices allowed the users to develop a set of health resources in the social, physical, cognitive and emotional dimensions, which helped them to advance their capacities of comprehensibility, manageability and meaningfulness ${ }^{21-2}$ in relation to life situations. The findings are consistent with Ericson et al. ${ }^{29}$ study regarding health resources perceived by older people in relation to physical activity. Furthermore, the findings support other studies ${ }^{8,12}$ that described users' perceptions of increased wellbeing, interpersonal relationships, attachment and physical health outcomes as related to their participation in the ASP.

Also, the present study reports additional health benefits than reported by previous studies ${ }^{8,12,29}$, relating to the improvement of cognitive, communicative and emotional skills among ASP's users. Then, the findings showed that the impact of ASP unit's activities on users' lives was broader than physical effects, such as physical fitness and pain relief. Importantly, the results provided an insight into an important element of health promotion work, that is, offering relevant experiences that may support the development of health resources among participants, thus, may help them seeing their lives as comprehensible, manageable and meaningful.

Regarding difficulties throughout health promotion work in the scope of ASP, the results supported other studies ${ }^{8,12,30}$ that identified a lack of procedures for monitoring actions, lack of integration with other health services, insufficient number of health professionals, and low quality of material resources and facilities. The present study adds to previous research by indicating that throughout the health promotion process, resistance arose from some users to experience new activities that were not focused on traditional approaches to physical activity.

This study had some limitations, among these, the problem of not involving other ASP units from different Brazilian geographical and cultural areas. Additional research is suggested to analyse how different ASP units have worked towards health promotion. Another limitation is related to the short duration of fieldwork. Despite this, the findings demonstrated to have correspondence with the particular reality of the ASP unit, as validated by the HPEP.

In conclusion, this study supported a better understanding of the health promotion work in the ASP. It provided practice-based evidence of possibilities to enable users to experience health development in the social, emotional, cognitive and physical dimensions. The findings confirmed the ASP's potential of providing meaningful experiences to users that might serve as health resources for them to draw upon and cope with challenging situations in life. Furthermore, the study offered examples of possible ways to enact health promotion process in the field of practice, which represents a significant contribution to knowledge on the implementation of health approaches. The key findings may support both future interventions and professional education, indicating alternative pathways for practitioners and undergraduate students to widen the scope of health promotion actions beyond the biophysical dimension. Finally, this study showed that by adopting a holistic perspective to the delivery of services and aligning work processes with health promotion theoretical foundations, such as salutogenesis theory, it may be possible to lead users to have meaningful experiences and to increase comprehensibility and manageability of their lives, which may result in greater self-perceived health and wellbeing. 


\section{Conflict of interest}

The authors declare no conflict of interest.

\section{Funding}

The study was financed in part by the Coordenação de Aperfeiçoamento de Pessoal de Nivel Superior - Brasil (CAPES) under Finance Code 001 and grant n. 88881.131900/2016-01; Federal Institute of Education, Science and Technology of South of Minas Gerais - IFSULDEMINAS; São Paulo Research Foundation (FAPESP) under grant n. 2019/05358-7.

\section{Author's contributions}

Ferreira $\mathrm{HJ}$ was responsible for literature search, data generation, data analysis and writing the manuscript; Kirk D contributed to the research project development, data analysis and critical review of the article. Drigo AJ participated in the research project design and development, and revision of the manuscript.

\section{Acknowledgments}

The authors acknowledge the collaboration of participants in the study, and the authorization provided by the Núcleo Municipal de Educação em Saúde Coletiva de Lajeado, Rio Grande do Sul to undertake the research.

\section{References}

1. Hallal PC. Academia da Saúde: mais um passo na direção certa. Rev Bras Ativ Fís Saúde. 2011;16(2):92.

2. Guarda FRB, Silva RN, Feitosa WMN, Santos Neto PM, Araújo Júnior JLAC. Caracterização das equipes do Programa Academia da Saúde e do seu processo de trabalho. Rev Bras Ativ Fís Saúde. 2016;20(6):638-49.

3. Sá GBAR, Dornelles GC, Cruz KG, Amorim RCA, Andrade SSCA, Oliveira TP, et al. The Health Academy Program as a strategy to promote health and healthy lifestyles: the national implementation scenario. Ciênc. Saúde Colet. 2016;21(6):1849-60.

4. Ministério da Saúde. Portaria n. 2.681, de 7 de novembro de 2013: redefine o Programa Academia da Saúde no âmbito do Sistema Único de Saúde. 2013. [citado em 2020 mai 7]. Disponível em: http://bvsms.saude.gov.br/bvs/saudelegis/ gm/2013/prt2681_07_11_2013.html

5. Ministério da Saúde. Política Nacional de Promoção da Saúde: revisão da Portaria MS/GM nº 687, de 30 de março de 2006. Brasília: Ministério de Saúde, 2014.

6. Lopes ACS, Ferreira AD, Mendonça RD, Dias MAS, Rodrigue RCLC, Santos LC. Estratégia de Promoção à Saúde: Programa Academia da Cidade de Belo Horizonte. Rev Bras Ativ Fís Saúde. 2016;21(4):379-84.

7. Florindo AA, Reis RS, Farias Junior JC, Siqueira FV, Nakamura PM, Hallal PC. Description of health promotion actions in Brazilian cities that received funds to develop "Academia da Saúde" program. Rev. Bras Cineantropom Cesempenho Hum. 2016;18(4):483-92.
8. Maciel MG, Saraiva LAS, Silva MM, Vieira Junior PR. Avaliação de desempenho do Programa Academia da Saúde em Belo Horizonte: um estudo de caso. Movimento (Porto Alegre). 2019;25:e25026.

9. Melo EHR, Guarda FRB, Feitosa WMN, Menezes VG. Classifying the types of evidence produced on the Academia da Cidade Program: a scoping review. Rev Bras Ativ Fís Saúde. 2019;24:e0076.

10. Feitosa WMN, Guarda FRB, Konrad LM, Gonçalves WSF, Martelli PJL, Araújo Júnior JLAC. Users' perception of actions, improvement in quality of life and satisfaction with the Academia da Cidade Program. Rev Bras Ativ Fís Saúde. 2016;21(5):461-69.

11. Silva KL, Sena RR, Matos JAV, Lima KMSV, Silva PM. Acesso e utilização da Academia da Cidade de Belo Horizonte: perspectiva de usuários e monitores. Rev Bras Ativ Fís Saúde. 2014;19(6):700-10.

12. Guarda FRB, Silva RN, Feitosa WMN, Farias JM, Santos Neto PM, Araújo Júnior JLAC. Self-perception of the objective, object and work products of Physical Education Professionals belonging to the Academia da Saúde Program. Rev Bras Ativ Fís Saúde. 2016;21(5):400-9.

13. Ivo MAS, Malta DC, Freitas MIF. Modos de pensar dos profissionais do Programa Academia da Saúde sobre saúde e doença e suas implicações nas ações de promoção de saúde. Physis (Rio J.). 2019;29(1):1-20.

14. Silva RN, Guarda FRB, Hallal PC, Martelli PJL. Avaliabilidade do programa academia da saúde no município do Recife, Pernambuco, Brasil. Cad. Saúde Pública. 2017;33(4): e00159415.

15. Melo VMC, Lemos EC, Marins AM, Silva BCR, Albuquerque AEMT, Aros LJL, et al. Performance of physical education professionals from the Academia da Cidade Program in primary health care in Recife. Rev Bras Ativ Fís Saúde. 2016;21(5):483-93.

16. Lemos EC, Bastos LLAG, Silva GB, Luna CF, Gouveia GC. Factors associated with adherence to the Academia da Cidade Program in Recife. Rev Bras Ativ Fís Saúde. 2016;21(5):470-82.

17. Charmaz K. Constructing grounded theory: a practical guide through qualitative analysis. London: Sage Publications, 2006.

18. Stenhouse L. The conduct, analysis and reporting of case study in educational research and evaluation. In: Mccormick R. et al. (Eds.). Calling education to account. London: Heinemann Educational Books, 1982. p. 261-73.

19. Rink J. Teaching Physical Education for learning. New York: McGraw-Hill Education, 2020.

20. Kolb SM. Grounded theory and the constant comparative method: Valid research strategies for educators. J. Emerging Trends Educ. Res. Policy Studies.2012;3(1):83-6.

21. Antonovsky A. Health, stress and coping. London: JosseyBass, 1979.

22. Antonovsky A. Unravelling the mystery of health: how people manage stress and stay well. San Francisco: JosseyBass Publishers, 1987.

23. Antonovsky A. The salutogenic model as a theory to guide health promotion. Health Promot. Int. 1996;11(1):11-8.

24. Mccuaig L, Quennerstedt M. Health by stealth: exploring the sociocultural dimensions of salutogenesis for sport, health and physical education research. Sport Educ Soc. 2018;23(2):111-22. 
25. Romeiro C, Nogueira J, Tinoco S, Carvalho K. O modelo lógico como ferramenta de planejamento, implantação e avaliação do programa de Promoção da saúde na estratégia de saúde da família do Distrito Federal. Rev Bras Ativ Fís Saúde. 2013;18(1):132-42.

26. Mcevoy L, Duffy A. Holistic practice:a concept analysis. Nurse Educ. Pract. 2008;8(6):412-9.

27. Pettigrew S, Burton E, Farrier K, Hill AM, Bainbridge L, Airey P, et al. Encouraging older people to engage in resistance training: a multi-stakeholder perspective. Ageing Soc. 2019;39(8):1806-25.

28. Rai R, Jongenelis MI, Jackson B, Newton RU, Pettigrew S. Factors influencing physical activity participation among older people with low activity levels. Ageing soc. 2019:1-21.
29. Ericson H, Quennerstedt M, Skoog T, Johansson M. Health resources, ageing and physical activity: a study of physically active women aged 69-75 years. Qual. Res. Sport Exerc. Health. 2018;10(2):206-22.

30. Paiva Neto FT, Mazo GZ, Sandreschi PF, Petreça DR, Rech CR. Barriers to implementation of Academia da Saúde program in Santa Catarina. J. Phys. Educ. (Maringá). 2019;30(1):1-10.

Received: 22/05/2020

Approved: 20/08/2020

\section{Quote this article as:}

Ferreira HJ, Kirk D, Drigo AJ. Qualitative analysis of the health promotion work in a Academia da Saúde programme's unit. Rev Bras Ativ Fis Saúde. 2020;25:e0128. DOI: 10.12820/rbafs.25e0128 